\title{
Historie, helse og makt i Dansk Vestindia
}

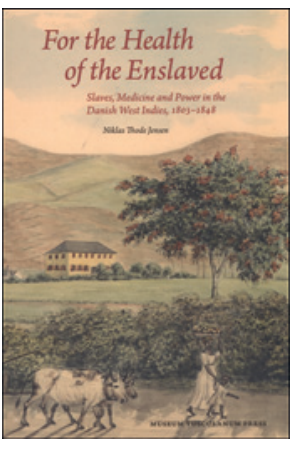

Dette er en bok med tema fra den gang Danmark var en kolonimakt og rådde over de tre øyene St. Thomas, St. Croix og St. Jan i Det karibiske hav. Den lukrative sukkerproduksjonen i Vestindia var arbeidskrevende og ble drevet ved hjelp av slaver som var å anse som plantasjeeiernes eiendom, på linje med redskap og buskap, slik det var vanlig i koloniene. Kritikken mot slavehold ble imidlertid etter hvert mer og mer hørbar. I 1803 ble import av nye slaver forbudt i Dansk Vestindia, og i 1848 ble slaveriet opphevet.

Det er perioden 1803-48 historikeren Niklas Thode Jensens bok handler om. I de årene oppsto nemlig et demografisk, medisinsk og økonomisk problem - høy dødelighet gjorde at slavepopulasjonen sto i fare for å bli redusert når det ikke kom tilskudd av nye individer utenfra. Helsetiltak måtte settes i verk for at ikke for mange slaver skulle dø og derved svekke den sårbare økonomien.

\section{Helse som arena for kontroll}

Forfatteren gir et veldokumentert innblikk i en interessant del av kulturhistorien. Illustrasjonene er velvalgte, og han refererer til et stort antall trykte kilder og til et meget omfattende og variert arkivmateriale i Danmark, USA og Vestindia. Han nevner også et stort

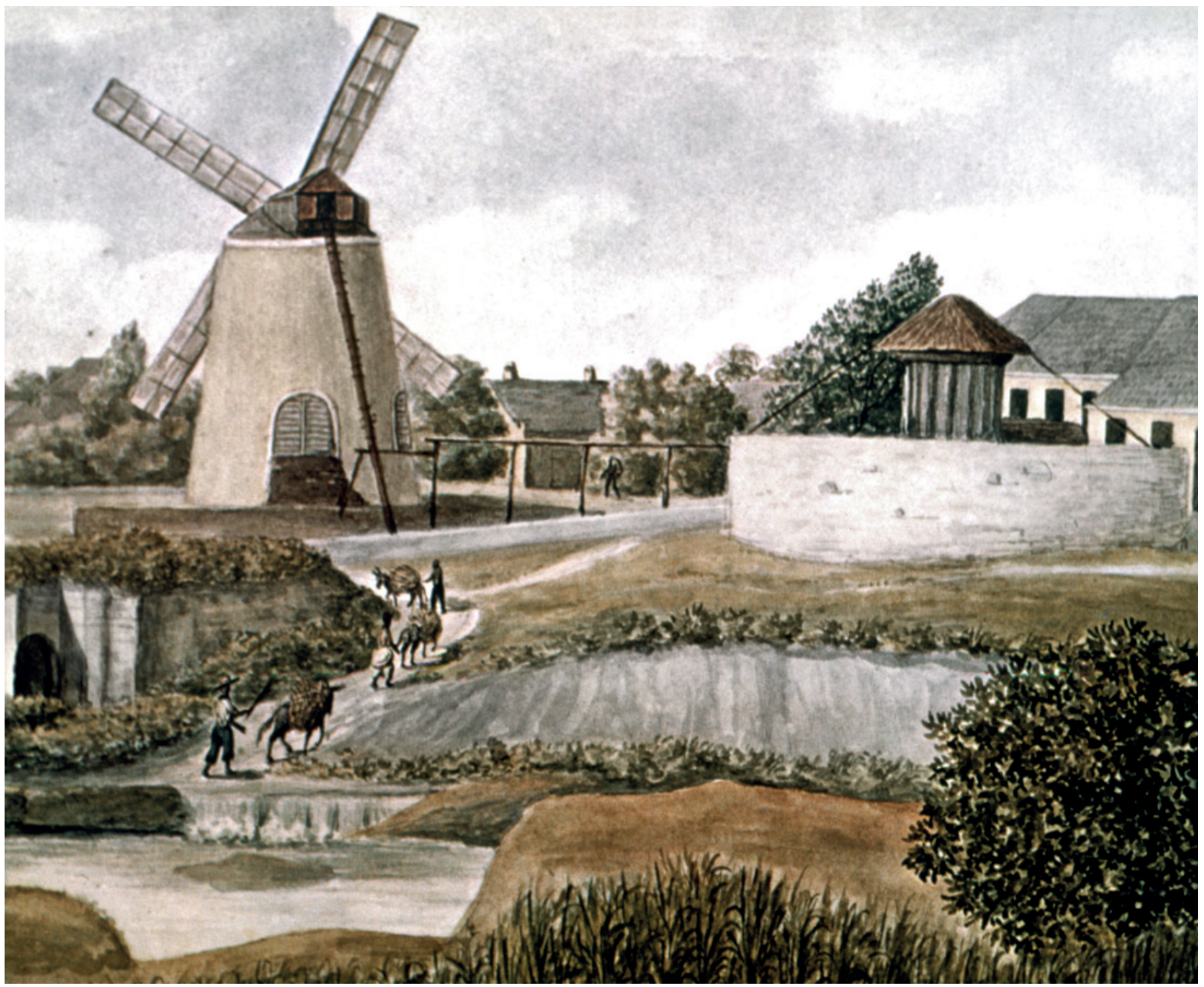


antall fagpersoner som har gitt ham råd og hjelp. Boken er en redigert og oversatt utgave av forfatterens ph.d.-avhandling fra 2006. Målgruppen er således den vitenskapelige verden, selv om boken er lettlest og fengslende også for andre.

Niklas Thode Jensens medisinhistoriske studie bør imidlertid leses på bakgrunn av dens hypoteser og intensjoner. Allerede i forordets annen setning flagger han sitt anliggende: «The inspiration originates from historians like David Arnold, Mark Harrison, Sharla M. Fett and others, who have shown that European medicine was used as a powerful tool for the colonisation and control of other people and countries.» Foruten å studere bl.a. helse og helsetiltak for slavene rent deskriptivt har han således et maktperspektiv helse som et styringsinstrument, og som en arena for kontroll. Her følger han tankegangen til Michel Foucault (1926-84).

Jensen sammenlikner sitt materiale fra danske vestindiske plantasjer med tilsvarende data fra engelske og franske øyer i samme område. Sammenlikningen er imidlertid ikke like god når det gjelder mer nærliggende grupper, f.eks. de lokale danskene eller især primærkontakten med omverdenen - sjøfolkene. Rigsarkivet i København har et omfattende og velordnet medisinsk materiale om helse blant marinepersonell som tjenestegjorde i Vestindia. Noe av dette materialet ble delvis bearbeidet i 1960-årene, men det kunne vært gjort mer. Jensen kunne sammenholdt sitt materiale med dette for å fortelle noe om sykdomsspredning mellom grupper, og derved også noe om effekten av helsetiltak for de ulike gruppene. Han har heller ikke brukt en sykdomsinndeling som kunne vært egnet for slik sammenliknende drøfting. I tyske og franske sosial- og medisinhistoriske miljøer ble det dessuten især i 1970årene gjennomført studier for å belyse interaksjonen mellom ernæring, hygiene, smitte, immunitet, fertilitet m.v. i historiske populasjoner som levde under marginale forhold. Erfaringene herfra antas å kunne ha vært av verdi for diskusjonen av Jensens data, likeledes synspunkter fra samtidig, 1800-talls medisinsk litteratur som beskriver medisinsk viten og praksis der og da.

\section{Sterk regulering av slavenes levekår}

Medisinhistorisk sett er hans kapittel Diseases, Therapies, and Causes of Death litt problematisk. I likhet med enkelte andre historikere prøver han å «oversette» medisinske diagnoser til våre dagers terminologi, altså angi hvilke moderne sykdommer som gjemmer seg bak fortidens begreper. Det halter. I en pre-mikrobiologisk tid dominert av smittsomme sykdommer var diagnostikken bygd på andre kriterier enn på de sykdomsårsakene, dvs. mikroorganismene, man først senere lærte å kjenne. Diagnoser kunne f.eks. være basert på symptomer som var felles for en lang rekke årsaker. Av og til kan man nok treffe riktig ved å «oversette», ofte ikke, men ulogisk blir det uansett. Innen den medisinhistoriske litteraturen er det atskillig oppmerksomhet om dette metodiske problemet. Det kunne vært tatt inn i diskusjonen.

Ettersom sykdommers sosiale funksjon er viktig for forfatterens problemstilling kunne det vært nyttig om man hadde drøftet mer hvordan synet på sykdom - og i tråd med dette - tiltak mot sykdom har utviklet seg. Forfatteren støtter seg her i hovedsak på Arthur Kleinman (f. 1941) og hans retning. Også andre «skoler» har arbeidet med dette. Bredde er viktig når man skal drøfte maktperspektivet, slik forfatteren har til hensikt. Hvilken verdi har f.eks. helse i forhold til andre verdier i den konteksten vi her befinner oss? Og hva er motivasjonen bak makten?

Ble helsetiltak brukt som offentlig, økonomisk begrunnet maktmiddel overfor slaveholdet i Dansk Vestindia 1803-48, f.eks. vedrørende ernæring, vaksinasjon og fødselshjelp? Forfatteren finner at den danske administrasjonen hadde en sterkere regulering av slavenes levekår enn man fant i sammenliknbare vestindiske kolonier. Danske myndigheter utøvde altså sterk administrativ makt, riktignok uten at dette ga seg nevneverdige utslag i helsetilstanden. Men var det utelukkende økonomisk kynisme som lå bak myndighetenes forordninger?

\section{Genuin omsorg}

Peter von Scholten (1784-1854) var en mektig mann i Dansk Vestindia i perioden $1814-48$, dvs. gjennom nesten hele den perioden Jensen beskriver. Fra 1827 var han fungerende, fra 1835 fullt utnevnt generalguvernør. Han var i realiteten den som hadde makten på den danske statens vegne. Jensen nevner riktignok generalguvernørens rolle flere steder, men kunne utdypet det bildet ettertiden har fått av den nærmest allmektige von Scholten: Han skal ha vært oppriktig opptatt av slavenes ve og vel. Han hadde gjennom mange år en farget elskerinne, Anna Heegaard (1790-1859), og dette skal ha bidratt til at han både forsto og støttet slavenes sak, tross plantasjeeiernes sterke motstand. I 1848 opphevet for øvrig von Scholten slaveriet i Dansk Vestindia på egen hånd (!), noe han måtte svi ettertrykkelig for etterpå. Men dersom den offentlige bruk av makt for å gjennomføre helsetiltak således også var motivert av genuin omsorg for slavene, ikke bare av økonomiske hensyn, må forfatterens utgangspunkt ses i et annet lys. Den maktutøvelsen han påviser, blir noe annet enn bare «colonisation and control».

Forfatteren omtaler mye meget bra forskning, men resultatet er ikke blitt så bra som det kunne ha vært. Tross sin grundighet har Jensen mest holdt seg til sitt eget faglige miljø. Historiens kontekst er preget av forfatterens kontekst.

\section{Øivind Larsen}

Institutt for helse og samfunn

Universitetet i Oslo 